\title{
A Study on Optimization of Biomass of Bacillus pumilus for Feather Degradation ${ }^{\dagger}$
}

\author{
S. Dhiva ${ }^{1}$, Afna ${ }^{1}$, Akshara ${ }^{1}$, Arya ${ }^{1}$, Dhanush ${ }^{1, *}$ \\ 1 Department of Microbiology, Sree Narayana College, Alathur, Palakad, Kerala, India - 678682 \\ * Correspondence: dhivasoju@gmail.com; \\ $\dagger$ Presented at International e-Conference on Bioengineering for Health and Environment (ICBHE 2020)
}

Received: 5.07.2020; Revised: 10.07.2020; Accepted: 12.07.2020; Published: 15.07.2020

\begin{abstract}
Soil samples were collected from the feather dumped area, and they were screened for the presence of keratinolytic bacteria Bacillus pumilus. Based on its growth on Bacillus isolation agar, Skim milk agar, and Starch agar, it was conformed as Bacillus pumilus. The growth of bacteria was estimated by biomass estimation. In the optimization study, the optimum incubation period observed for feather degradation was $48 \mathrm{hrs}, \mathrm{pH} 7$, and temperature $40^{\circ} \mathrm{C}$. Purified Keratinase enzyme was used for the feather degradation study. The maximum degradation observed was $29 \%$ at the temperature of $40^{\circ} \mathrm{C}$. The size of kerinase produced was estimated as $52 \mathrm{KDa}$.
\end{abstract}

Keywords: Keratinase; feather; keratinolytic bacteria; spectrophotometer.

(C) 2020 by the authors. This article is an open-access article distributed under the terms and conditions of the Creative Commons Attribution (CC BY) license (https://creativecommons.org/licenses/by/4.0/).

\section{Funding}

This research received no external funding.

\section{Acknowledgments}

This research has no acknowledgment.

\section{Conflicts of Interest}

The authors declare no conflict of interest. 